\title{
Students' Leadership in Selected Public Universities in Kenya: Disfranchised Pressure Groups or an Integral Component in University Management?
}

\author{
Bosire, Joseph, C. Chemnjor and M. Ngware
}

\begin{abstract}
This paper was based on an exploratory study carried out on student leadership in three public universities in Kenya in 2004/2005 academic year. The study was premised on the challenges facing student leadership and the transformative roles student leadership plays in the management of student affairs and overall university management. Data were collected using a self-administered questionnaire from a sample of 34 student leaders and analyzed through descriptive statistics. Findings showed that most student leaders were first born in their families. Most of the students' parents were in low to middle level occupational category in the public sector, with about $50 \%$ of them having attained at least some college training. Most of the students resided in urban centers, with a significant majority coming from the major urban centers in the country - namely, Nairobi, Kisumu, Eldoret, Nakuru and Nyeri. Student leaders were prompted to leadership interests by many factors, including past leadership experience in high school, service to students, a learning experience, and to develop a culture of dialogue with university management. Despite these values and intentions, student leaders still faced many challenges in their efforts to achieve the intended goals. This ranged from institutional rigidities, high student expectations and skepticism, betrayal from students' body, low participation rates by female students and tribalism/regionalism. This study observed the transformative nature of student leadership compared to what it was two decades ago and encouraged that student leadership is an integral component of modern university management
\end{abstract}




\section{Introduction}

Universities in Kenya are going through various challenges brought about by globalization, scientific and technological developments and a competitive environment. By implication, one of the immediate responses to these challenges is the creation of a system of governance and leadership that provides a forum for effective representation of all stakeholders, particularly the students. This paper discusses research findings on student leadership as one of the interactions offered by universities and which affects both the academic and social dimensions of student life on campus. Student leadership in the form of student governance is an input into the education process and an important component in the university management system (Republic of Kenya, 2000; Katana, et. al., 2006). Specifically, the paper centres on research findings on some of the social and schooling background characteristics of the student leaders as a basis for appreciating their roles in the management of the student body. This is in view of the crucial role the student leadership plays in assisting and oftentimes influencing, directing and guiding university management in making certain decisions on student affairs and management in such areas as student welfare, academic matters, examinations and national issues.

\section{Background}

\section{Structure and Functions of the Student Union}

Kenya has seven public universities, five of which were commissioned within the last one and half decades. The seven public universities are Nairobi, Kenyatta, Moi, Egerton, Jomo Kenyatta, Maseno and Masinde Muliro. These universities have between them a total enrolment of about ninety thousand $(90,000)$ thousand students registered under full time and part time modes of study (Republic of Kenya, 2007).

Each of the public universities has a student governing body referred to by different names as the student union, government or congress. Whichever title used, this is a body that represents a student parliament that has office bearers who are elected after each academic 
year. The function and structure of the student union in Kenya's public university system is more or less similar to that in other universities in the rest of the world. Generally, the student union is both a student platform for addressing various social, political and corporate issues of the student community and a link between students and university management (Egerton University, 1999a)

In Egerton University, as is likely the case in other public universities, the student union is catered for in the university Act and Statutes (Egerton University, 1999a; 199b). The union plays an integral role in university management as it contributes to decision-making on matters affecting students' academic and social life on campus. It is registered in the office of the Dean of Students and approved by the University Senate. The students' government comprises of the following nine key offices and office bearers with designate functions (SUEU, 2002):

- The executive chairman

- The executive vice chairman

- The secretary general

- The organizing secretary

- The treasurer

- Director welfare

- Director academics

- Executive secretary

- Director sport and entertainment

These titles may differ from one university to the other, but generally spell out the main offices, which also make up the Executive organ of the union, or Students Representative Council. The other two organs are the Students Governing Council and the Committees of the union. The former consists of the executive, constituency representatives, year representatives, religious representatives, representatives of clubs and associations, non-resident students, sports and entertainment and corporate members. The latter are a creation of the executive and consist of but not limited to the Academic Affairs Committee, Welfare 
Committee, Finance Committee, Students' Center Committee, External Affairs Committee, Sports and Entertainment Committee, Editorial Committee and Discipline Committee (Barasa, 2002).

Viewed from this perspective, the student union is therefore a legally binding institution recognizable in university administration and governance. It has a guiding constitution that determines and controls the activities and responsibilities of the leaders to the student body and to the university as defined by the various organs. As a legal entity, the students' union has various rights and obligations such as holding term elections, collecting funds, organizing meetings and disciplining its members. In addition, the union is responsible to university management in the following areas:

1. Assisting management in determining decisions that affect the student body

2. Serving as a communication link between the student body and management

3. Consulting and debating with the student body on issues of mutual interest

4. Guiding the students responsibly

Given the nature of the various offices, responsibilities and functions as defined in the students' constitution, it is observed that the student leaders are obligated to serve their electorate conscientiously but having the expectations of university management in mind. Often times, they find themselves hard placed not to be compromised by either the students or the university management as defined by the Security of Office in the constitution of the union [refer article 13 (3), (4) and (5) of the SUEU Constitution].

This is a delicate role, especially when viewed against the problems facing university education in Kenya today. Such problems include high student enrollment against scarce resources in accommodation and tuition facilities, poor and inadequate instructional facilities, 
scarcity of teaching staff, unclear government policy on university education and reduced state funding (Unesco, 1998; Brock-Utne, 2003). This situation is aggravated by the continued changes in the economic and social environments, characterized mainly by structural cost cutting policies, globalization, enhanced freedoms and rapid growth of knowledge and technology (Adam, 2003; Sall \& Kassimir, 2003).

The ultimate bearers of these challenges are the students and university managers who have to adjust their expectations according to the prevailing conditionalities. Particularly, universities have to implement policies that are largely in contravention of natural justice and individual beliefs (Brock - Utne, 2003). On the other hand, the student leader is expected to be understanding and persuade the rest of the student body to contend with the situation as it may be. Such situations result in poor education discourse, delivery, and unfulfilled dreams about university education, which ends up in delicate relationships between the students and university management. The student leader has to bear the pressure from both sides and play the conciliatory arbitrator.

Given the nature of the constitution of the student union and the roles the student leaders are expected to play, it is vital to understand the nature of the persons elected into office, their experiences in office and what some of their observations are about student leadership in the university. Exploring into the background characteristics of student leaders, may aid in shading light on important aspects about the character of student leaders that might lead into redefining student roles in the collective management of universities. It is on this basis that this study sought to answer the following specific questions.

1. What are the educational and socio economic background characteristics of student leaders in public universities in Kenya?

2. What factors prompt students to be interested in leadership positions in student organizations? 
Student' Leadership in Selected Public Universities in Kenya...

3. What are the challenges that student leaders face in executing their leadership roles in the universities?

4. How do student leaders rate female student participation in student affairs in public universities?

The nature, scope, structure and focus of student leadership and student organizations have differed over time and between countries since universities were founded (Katana, et al. 2006). In addition, the variety and changes in the nature and interests of student leadership has generally tended to correspond to and been determined by the nature and purpose of the organizations they represented (Republic of Kenya, 2000). For example, student organizations range from social groups interested in transcendental meditation to activists of selected political parties (Kuh, 1983).

The character of the student organization and the values for its formation largely influenced the character of their student leaders. In the early days of university education, student organizations were social leisure clubs representing children of the upper class in society, such as the German fraternities (Cohen, 1993). These were later to evolve into organizations that cared for a variety of student interests and needs - physical and material life and those promoting political and cultural interests. Other student organizations were based on and concern with the different subcultures in the student fraternity, such as tribal, religious, academic groups, health, housing, sports, and finances.

The nature of student organizations, and student leadership changed over time with changes in social values, technology and the character of higher education, from performing primarily social and religious functions to highly charged political revolutionaries and activists in the mid and late twentieth century. University student leaders have been seen more as abrasive young politicians critical of the existing establishment and seeing a renaissance in the making (Barasa, 2002) 
The upsurge of student activism associated with radicalism in student leadership in the 1930's in USA and in Kenya in the 1970's was blamed on faculty professors who were thought to be teaching 'communism', 'socialism' and anarchy (Cohen, 1993). These were then regarded foreign ideologies which were perceived as being anti establishment. As a result, student leaders were always under the watchful eye of the state's security operatives. A number of them hardly completed their university education without incarceration or just expulsion from the university altogether.

Other factors have been advanced to explain the context of the radical and often confrontational student leadership styles in universities. One key factor is poor or depressed economic performance, which has the vicious effect of reducing family incomes, student subsidies on books, accommodation and catering and poor prospects for job placement. The net effect of this is reduced student budget, increase in tuition fees, unemployment and underemployment of highly trained labour force, and growing resentment towards existing order and political establishment (Brock-Utne, 2003; Mugabushaka et, al. 2003).

At this stage, students perceive that they have acquired sufficient knowledge and skill to overthrow that establishment (Cohen, 1993). Such a situation arose in Kenya in the mid 1980's through to the 90's when the government withdrew payment of the students' semester stipend and introduced a new student loan scheme and user charges in its cost sharing policy. The economic theory of campus radicalism following resistance from student leadership partly explained the frequent closures of public universities in Kenya in the 1990's. Economic hardship is such a fluid factor that aspiring student leaders are always inclined to use it to gain advantage during union/leadership campaigns. One student leader subtly put it in attempts to rally the student fraternity of Kenyatta University in 1982 ahead of the attempted mutiny by the Kenya Air force against a proposal by the state to introduce a modified student loan scheme thus: 
...In science, if you want to kill a frog, you need to put it in cold water and then heat the water gradually, but if you put it straight into hot water, it will jump out sooner than later.

Social class is another factor that has been used to explain student activism. The limitations of using class analysis as a mode of understanding student activism in the 1930's were observed in the composition of student leadership in the USA. While it was widely believed that student leaders came from economically humble family backgrounds, Cohen (1993) noted that there existed some from affluent families. For instance, at the Illinois campus, $45.8 \%$ of student activists came from affluent families as compared to the overall student body of which only $17.9 \%$ were from households headed by fathers in the professions. The proportion of working class students was also lower in the Illinois student leadership than it was in the student body as a whole $-8.3 \%$ of the student radicals came from blue-collar homes as opposed to $15.2 \%$ in the overall student body (Cohen, 1993).

Cohen (1993) attributes the family members, and not the faculty professors as major players in influencing students' inclinations towards student leadership in universities. Generally, the reasons for students resorting to leadership roles in the university included fascism, economic hardships, middle class guilt, fears of insecurity, egalitarianism and the influence of progressive parents and teachers. These reasons could be applicable in one type of region and not the other, or in different campuses depending on a variety of social political and economic contexts.

\section{Methodology}

This study was exploratory in design. Three public universities, namely, Egerton, Maseno and Moi, were involved and all the student leaders on campus were given a self-developed questionnaire for completion. The questionnaire had twenty-seven items. Six items 
were on a rating scale. They were used to collect data on student perceptions on the participation of female students in student leadership in the universities. The rest of the items were open ended and collected data on diverse aspects of the student leaders' socio economic and schooling backgrounds. Out of 55 questionnaires sent out, a total of 34 respondents accepted to participate. This represented a response rate of about $62 \%$. Maseno had the highest responses, (17), Moi (6) and Egerton (11). The response rate from Maseno was high mainly because two groups of student leaders were on campus by the time of the study. They all responded to the questionnaire.

Some students declined to participate for fear of victimization. None of the student leaders from Jomo Kenyatta University of Agriculture and Technology and Kenyatta University responded to the questionnaire. This was despite efforts of assurances on confidentiality and the academic rather than administrative purpose of the research. The collected data were analyzed descriptively using frequency counts and percentages. Some variables were crosstabulated to investigate possible associations between certain characteristics and specific universities. Particularly, the variables analyzed were residential backgrounds of student leaders and student opinions on female students' participation for leadership positions in the unions.

\section{Findings}

Socio-Economic Characteristics of Student Leaders

Students' Birth Order in Family

Data was collected on the birth order of the student leaders in their families. Table 1 shows that most (38.2\%) of the student leaders were first borns in their families. This was contrary to expectations. In an African set up, first-born children are usually expected to take up 
family responsibilities of guiding their younger siblings and nurturing them into responsible beings.

Analysis in table 1 shows that students politics in Kenya has been a risky responsibility, at least going by past events in which student leaders were arrested, imprisoned and expelled from universities because of involvement, perceived or otherwise, in university strikes by students (Republic of Kenya, 2000). Following this line of argument, it would be expected that first born students would not take the risk of taking active roles in student politics. Therefore these findings become a sort of an anticlimax. On the other hand, however, since first borns are expected to lead by example from their homes, then they would as well naturally fit into student leadership roles (McClelland, 1962).

\section{Parents' Occupation}

Respondents were asked to indicate the occupations of both of their parents in cases where it was applicable. Table 2 provides a summary of the results. The data shows that most of the students had both parents in formal employment positions with a majority (93\%) in public sector employment. Further examination of the data reveals that most of these students had parents in low to middle level civil service positions such as clerical, teaching, nursing, printing, engineering and survey. None of the parents occupied executive government or private employment positions. The proportion of students whose parents were either unemployed or in small-scale farming (27\% of the fathers and $42 \%$ of the mothers) is significant. Similarly, it was found that most $(68 \%)$ of the students' fees were paid by both parents. The distribution was such that about $12 \%$ of the students had their fees paid by the mother only, $9 \%$ by the father only and $47 \%$ by both parents.

\section{Parents Education Levels}

It was thought that the parents' education level was an important factor in further enhancing our perceptions and understanding of the 
characteristics of university student leaders. In this respect, data was collected on the level of education attained by the parents of student leaders. The details of the findings are given in table 3 . The distribution of parents by their education levels is almost similar between mothers and fathers, especially below primary level of education (39\% for the mothers and $36 \%$ for fathers). Generally, most of the parents were schooled at least above primary level. More mothers $(56 \%)$ had attained above secondary level of education compared to the fathers $(49 \%)$, with the greatest difference in the mothers' favor being at college training.

\section{Students' Residential Location}

This study attempted to establish the home backgrounds of the student leaders. Specifically, the focus was to find out whether the students lived within or outside urban environments. The results are highlighted in tables 4 and 5. Table 4 shows that about $56 \%$ of the student leaders resided within major urban environments of the country such as Nairobi, Kisumu, Eldoret, Nakuru, Kisii and Nyeri. A lesser proportion (41\%) of the students came from urban centers with a lesser threshold of activities. This data was analyzed further to establish and compare the distances of the students' residential homes from the nearest urban centers. This information is described in table 5 which shows that half of the students lived within ten kilometers radius of the various categories of urban centers. A lesser proportion of about $25 \%$ lived in likely typical rural environments. When the data was cross-tabulated according to university, it was found that relative to the other universities, Maseno University had a bigger proportion $(76 \%)$ of its student leaders coming from major urban environments

\section{Students' Selected Educational Backgrounds}

Students studying in public universities are selected from various secondary schools from across the country. Selection is usually based on students' choice of the course and preferred university based on academic merit. Data for this study was collected to determine what 
regions of the country and school categories student leaders came from.

\section{Location of Schools Attended by Student Leaders}

Students were asked to indicate where they studied in their secondary education. The data was tabulated in terms of regional location of the school according to the provincial regions of the country. These results are summarized in table 6 . The results in table 6 indicate that most $(38 \%)$ of the students studied in schools within Western Province with Rift Valley and Nyanza provinces sharing 42\%. This trend reveals a general pattern where most students attend schools and universities close to their home locations.

\section{School Category}

Public schools in Kenya are classified in a hierarchical order based on government support and catchment areas in student admission. The highest categories are the National schools, which admit students from across the country on a district quota basis, followed by the Provincial category, which admit students from across the provincial region. The District school category admits most of its students from the local district region. In addition, there are schools in private ownership by either individuals or organizations. These may be either low cost or high cost depending on the amount of fees charged. For purposes of this study, high cost schools were designated as those charging above fifty thousand Kenya shillings (KES 50,000) per year.

Students were asked to indicate the category of schools they attended before joining the university. Details of the data are given in figure Figure 1 shows that most $(53 \%)$ of the student leaders attended Provincial schools and a significant proportion (29\%) had attended National schools. However, this reflects the general admission pattern of students into the public universities in Kenya, where the majority of the students come from the National and Provincial school categories. Further inspection of the data reveals that the students come from the 
popular and mainstream schools, such as Lenana School, St. Mary's Yala, Nyeri High, Mangu High, Nairobi, Cardinal Otunga High School, Musingu, Nakuru High, Moi Forces Academy and Starehe Boys. Most of these schools were single sex and boarding type.

\section{Prompters of Student Interests in Leadership Roles in Student Organizations}

What makes students to be interested in leadership positions in the politically inclined and often conflict minded and controversy driven student organizations? In attempting to respond to this question, the study sought to find whether the students were in any leadership positions in their secondary schools prior to joining the university.

\section{Initial Administrative Responsibilities in Secondary Schools}

Leadership positions in schools are largely on appointment by the school administration. Appointment is usually based on show of good conduct and respect to both the students and school authority. About $82 \%$ of the student leaders were in various leadership roles in their schools as shown in the distribution in table 7. Table 7 shows that most (64\%) of the student leaders had been involved in the three key areas of school administration - sports (25\%), general administration (21\%) and accommodation (18\%). From this, it may be perceived that student participation and involvement in school administration may have been a vital precursor to their leadership interests at the university level.

\section{Reasons for Interest in Student Leadership at the University}

Student leaders were asked to list the factors that prompted them to be interested in leadership positions in the respective student unions. The respondents gave several reasons, which were interpreted as summarized in table 8 . The reasons students gave for developing interest in leadership positions are diverse and significant. The most popular reason was to serve student interests, such as addressing common student problems with university administration. Some of the explanations given under this prompter included the following: 
Student' Leadership in Selected Public Universities in Kenya...

- Protect students interests from dictatorial administrators

- Pressure from students for quality and committed leadership

- To bring about visionary leadership to student organizations

- To bargain for and champion the rights of the students

Fifty percent of the students perceived participation in student leadership as a training and learning experience, an opportunity for personal development in political and economic terms and a preparation for future roles in national politics. Some of the students expected financial gains in leadership, while others thought it was prestigious to be a student leader at the university.

The idea of harmonizing student leadership with the administration, though given by only $24 \%$ of the students, is worthy a special note. Some of the explanations given on this point included the following:

- Develop a culture of dialogue and constructive consultations by students and university administration

- Improve the bad public image of university students

- Change the students' mentality to understand university administration, not to be seen as opposition

- Bring back the lost glory of the students governing council

These explanations point out a positive attitude and endeavor by the students to bridge the university administration and the student body towards a harmonious co-existence. This implies that amongst the student leadership, there are some that are intent on nurturing a reconciliatory and consultative approach to solving problems on campus. 


\section{Challenges to Student Leadership in Public Universities}

Student leadership has been described as a very risky undertaking, especially when viewed in a historical perspective from what happened to previous student leaders in the 80's and 90's in Kenya. Student leaders are aware of some of these challenges, which they gave as summarized in table 9. The most challenging situations are presented by the high student expectations on student leaders, balancing between academic work and leadership service to the student body and the limited finances for performing their tasks effectively. Interestingly, fear of victimization was not a major challenge as would have been expected. This similarly applies to external influences and interferences, which has usually been seen as a major factor fueling up student conflict with university administration.

One other interesting observation is the false image of student solidarity, which implies that the student body may not be trustworthy, are unpredictable, can be traitorous and betray a common course of action. It also implies that the student body may present a pretentious image and inflate an insignificant issue just to course trouble and put the leaders to test. These are conditions that can betray the essence of comradeship and student power, which are rallying sentiments for common participation in solving a given issue on or outside campus or the domain of university administration.

\section{Factors that Influence Student Activism in Public Universities}

Respondents were asked to indicate the factors that influence student activism on or outside campus. The findings are summarized in table 10.Major causes of student politics and possible subsequent trouble are the students themselves (59\%), poor administration models (47\%) and external pressure from other campuses and trends in national politics $(38 \%)$. The status of infrastructure and academic services do not seem to be significant factors. The element of ethnicity seems to be cropping up as one of the factors seen to be contributing to campus politics. 


\section{Female Student Participation in Student Politics in Public Universities}

Out of the 34 respondents, female students were only seven (21\%). Of the seven, five were from Maseno University and two from Egerton. This implies that male students dominate student leadership in public universities. Using a five point rating scale, respondents were asked to rate female students' participation in six key aspects (indicators) of student leadership on campus. The results are summarized in table 11. The data in table 11 shows what the student leaders perceived about female students' participation in student leadership in the university. Generally, most of the respondents view female participation in student meetings, interest in student affairs and interest in leadership positions as noncommittal and poor. Less than $30 \%$ of the respondents rated them as at least good while more than $30 \%$ felt they performed poorly on these three points. On the other hand, most of the student leaders viewed the response of other female and male students and the university administration to female student leaders as generally good and supportive. Generally, more than $40 \%$ of the respondents gave a positive rating compared to less than $20 \%$ that gave a negative rating on these aspects. Particularly, $56 \%$ of the respondents felt that the university administration was positive about female students' participation in student affairs. This is remarkable compared to less than $10 \%$ who felt otherwise.

\section{Discussion}

Normative models and principles consistent with bureaucratic thinking have been used in analyzing, explaining and predicting student behavior, organization and affairs. The basic assumption has been that student organizations function in a rational and predictable manner. However, lately, scholars have been involved in a paradigm shift and questioned these models in the overall management of student affairs (Kuh, 1983). The focus of this study was to explore into the background characteristics of university student leaders as a basis of understanding their behavior patterns in the management of student affairs and the overall administration of the university. 
Specifically, this observation was made within the public perception and belief that the university student leader and in fact university student in Kenya is irrational, socially and economically irresponsible and bent on anarchism.

\section{Background Characteristics of Student Leaders}

Background characteristics of university student leaders are an important aspect in understanding, interpreting and perhaps predicting their general behavior. Using behaviorist theories, it is argued that a person's conduct and behavior inclination is dependent on the growth environment. The growth environment is a factor of the natural environment, culture and tradition. The latter two may be established deliberately in order to nurture a certain kind of desired and common behavior pattern conforming to given ethos and norms in society.

This study found that the student leaders came from diverse home environments. A majority of them belonged to middle and lower income families where both or at least one of the parents was in formal public employment (44\%). A significant proportion had parents who were either in self-employment $(21 \%)$ or unemployed (21\%). In addition, more than 55\% of the parents had attained secondary education and above, while less than $25 \%$ had dropped out at primary school level. Similarly, the study found that about $90 \%$ of the student leaders had studied in mainstream Provincial and National secondary schools before joining the university. By virtue of the climate established by the tradition of such schools, it would be expected that the students would develop behavior attributes that are likely to espouse leadership inclinations (Ngoyani, 2000; Cohen, 1993).

Similarly, most (56\%) of the student leaders came from home backgrounds located within or close to urban environments in major towns of the country (less than $20 \mathrm{~km}$ radius). These are urban centers with higher threshold of activities in commerce and administration. Such urban characteristics have greater influence in shaping an 
Student' Leadership in Selected Public Universities in Kenya...

individual into an informed and cosmopolitan character than rural centers by virtue of the latter's limited nature and degree of information and interaction.

\section{Prompters for Student Interests in Leadership Roles}

Several factors were given to explain the reasons for student interests in the historically volatile student politics on campus. The main driving force stated by a majority of the respondents (82\%) was serving the diverse student interests. However, student leaders also indicated personal interests such as the need for recognition, prestige or self-actualization as the driving factors. A relatively small but significant number indicated the intention to use student politics for arbitration and reconciliation with university administration and as a training ground for future political interests on a wider scale. It was also found that prior to joining the university, most $(82 \%)$ of the students leaders had participated in the school administration of their schools in various capacities, such as school prefect, school sports captain and house captain. Such leadership experiences may have prompted the students to vie for leadership positions in the student union.

What prompts students to be activists on campus? This is a behavior attributed to and has become characteristic of students in public universities (Republic of Kenya, 2000). This study found three main causes of student activism on campus, namely student propaganda (59\%), poor management models $(47 \%)$ and external influences (38\%). Ethnicity, though identified by a minority of respondents seems to be a critical emerging factor in explaining some of the propaganda insinuations that snowball into major crises on campus.

Students' Perceptions on Female Student Participation in Student Affairs on Campus

The study sought to establish the students' views and perceptions on the participation of female students in student affairs on campus. A very small proportion $(21 \%)$ of the student leaders was female. 
Generally, the findings indicate that female participation in student affairs on campus is poor. This is in spite of the perceived view by the respondents of very positive support from both the university administration and the male students.

Student leaders in public universities face several challenges. This study found three major challenges that the student leaders face on campus, namely high student expectations (53\%), conflict of interest between academic pursuits and leadership objectives and fake or pretentious student solidarity $(23 \%)$. Of the three, the latter is intriguing in the sense that it spells mistrust of the student leaders on their electorate and confounds effective and representative decision making in the wake of a crisis or issue to be addressed by the leaders.

\section{Conclusion}

The basic question that emanated from this study was whether student leaders in public universities are a disfranchised pressure group or an integral part in university management. Generally, the nature of student leadership in terms of ideology, assertiveness and perhaps even social standing has changed over time, especially compared to the 1980's and 90's. Many factors have been advanced to explain this change, but largely, the changes in the politico-economic environment and inclinations of the country could stand out as critical. For example, the advance of cost sharing policy in university financing, advent of political pluralism and changes in the admission policies into university have diverse contributions but similar explanations to student political activism on campus. The results of the study have indicated that student leaders come from relatively similar education, location and socio-economic backgrounds. With respect to the latter factor, most student leaders come from humble to middle income parentage.

Similarly, students are prompted to face the risky challenges of university student leadership roles by many factors. However, a number of the leaders implied they were interested in harmonizing the 
often-volatile relationships between the student community and the university administration. The rather conservative administrative models employed by the universities resulted in otherwise avoidable conflicts with the neo-liberally inclined university students (Katana, 2006; Weber, 2007).

In this respect, it would be interesting to establish what happens in private universities and the kind of student leadership that is in place in such institutions. It might also be worth the while to make a more detailed analysis of student leadership in other public universities in the East African region. Nonetheless, university administrators need to realize the need to re-examine the suitability of the management models used in university administration to the character of the contemporary university student. It is the view of this study that the university student leader, given the context of the over-all university climate is an integral contributor to any and every aspect of university management.

\section{Special Acknowledgement}

Appreciation to the student leaders in Egerton, Maseno and Moi Universities during the academic years 2003/2004 and 2004/2005 for the responses they gave which realized the production of this research report. 


\section{References}

Adam, L. (2003) Information and communication technologies in Higher education in Africa: Initiatives and Challenges. Journal of Higher Education in Africa 1 (1),195 - 221

Barasa, S. (2002). Disabusing student Politics on Campus, Coffee Connection, March, p 19.

Brock-Utne, B. (2003) Formulating High Education Policies in Africa: The Pressure From External Forces and the Neoliberal Agenda. Journal of Higher Education in Africa 1 (1), 24 - 56.

Cohen, R. (1993). When the Old Left Was Young: Student Radicals and America's First Mass Student Movement, 1929 - 1941. New York: Oxford University Press.

Egerton University (1999a) Egerton University Calendar, 1999/2000, Njoro: Education Media Center.

Egerton University (1999b) Egerton University News. Njoro: Education Media Center. August, p. 12.

Katana, G., Fremerey, M., \& Amini, S. (2006) Proceedings for the 1st internationalConference on Quality Assurance in Higher Education, Kenyatta University, 6th to 10th November 2006

Kuh, G. D. (1983). Understanding Student Affairs Organizations, London: Jassey-Bass Incl. Publishers.

McClelland, D. (1962). The Achieving Society. London: Macmillan Ltd

Mugabushaka, A.M., U. Teichler and H. Schomburg (2003) Failed or Self - Hindering Prophesies? Employment experiences of African graduates in the 1990's. Journal of Higher Education in Africa 1 (1), 57 - 77.

Ngoyani, D. (2000). Tools of Deception: Media Coverage of Student Protests inTanzania. Nordic Journal of African Studies, 9 (2), $22-48$.

Republic of Kenya (2000) Report of the Vice Chancellors' Committee on Causes of Disturbances/Riots in Public Universities.

Nairobi: Government Printer

Republic of Kenya, (2007), Economic Survey, 2007. Nairobi:

Government Printer 
Student' Leadership in Selected Public Universities in Kenya...

Sall, E., Y. Lebeau and R. Kassimir (2003) The Public Dimensions of the University in Africa. Journal of Higher Education in Africa. 1 (1), 126 - 158.

Shabani, J. (1998). Lifelong higher education for all in Sub-Saharan Africa. In Higher Education in Africa: Achievements, Challenges and Prospects. Dakar: Unesco.Pp 57 - 78

SUEU (2002). Students Union of Egerton University Constitution, Egerton University,

Unesco (1998) Higher Education in Africa: Achievements, Challenges and Prospects.Dakar: UNESCO

Weber, L.E. (2007) University Governance, Leadership and Management in a Rapidly Changing Environment. A Paper presented at the International deans Course, University of Applied Sciences, Osnurbrueck, Germany, 18 ${ }^{\text {th }}$ May 2007

Fig.1 Distribution of students by school category

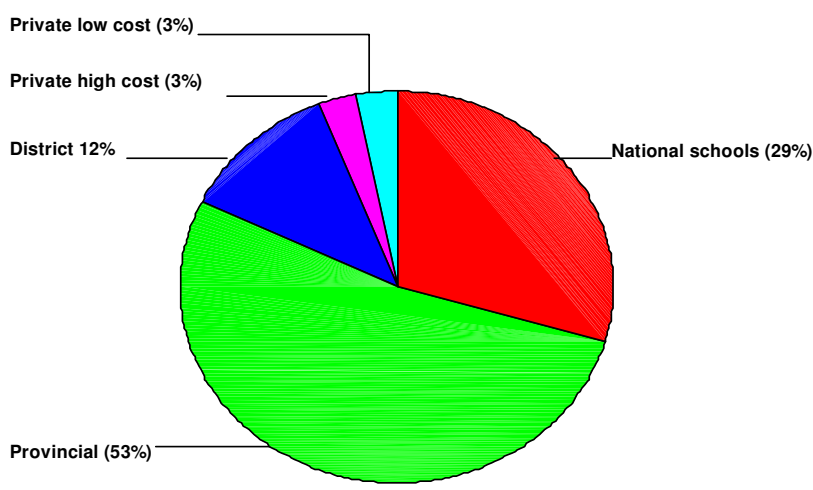


Table 1: Distribution of student leaders by birth order in the family $\mathrm{N}=34$

\begin{tabular}{lcccc} 
& & & \multicolumn{2}{c}{$\mathrm{N}=34$} \\
\hline First & 13 & 38.2 & 38.2 & 38.2 \\
Second & 7 & 20.6 & 20.6 & 58.8 \\
Middle & 6 & 17.6 & 17.6 & 76.5 \\
Last & 8 & 23.5 & 23.5 & 100.0 \\
Total & 34 & 100.0 & 100.0 & \\
\hline
\end{tabular}

Table 2: Distribution of students' parents by occupation type $\mathrm{N}=34$

\begin{tabular}{lcccc}
\hline \multicolumn{1}{c}{ Occupation } & \multicolumn{2}{c}{ Father } & \multicolumn{2}{c}{ Mother } \\
& Frequency & Percentage & Frequency & Percentage* \\
\hline & 3 & & 2 & 6 \\
Self employment & 4 & 9 & 1 & 2 \\
$\begin{array}{l}\text { Formal employment } \\
\text { (Private) } \\
\quad \text { Formal employment } \quad \text { (Public) }\end{array}$ & 12 & 12 & 15 & 44 \\
$\begin{array}{l}\text { Farming (Small scale) } \\
\text { Unemployed }\end{array}$ & 7 & 35 & 7 & 21 \\
No response & 2 & 6 & 7 & 6 \\
Total & 6 & 17 & 2 & 100 \\
\hline
\end{tabular}


Student' Leadership in Selected Public Universities in Kenya...

Table 3 Parents' education levels

$$
\mathrm{N}=34
$$

Education level

$$
\text { Mother }
$$

Father

Frequency Percentage

Frequency

Percentage

*

Not schooled

4

12

3

9

Primary school

dropout

4

12

4

12

Primary school leaver

5

15

5

15

Secondary school

leaver

College training

0

12

0

35

2

8

6

University training

7

21

9

25

Not applicable

2

6

3

9

Total

34

100

34

100

Table 4 Distribution of students' by nearest residential centre $\quad \mathrm{N}=34$

\begin{tabular}{lcccc}
\hline & Frequency & Percent & Valid Percent & $\begin{array}{c}\text { Cumulative } \\
\text { Percent }\end{array}$ \\
\hline Major city & 7 & 20.6 & 20.6 & 20.6 \\
Municipality & 12 & 35.3 & 35.3 & 55.9 \\
Town & 14 & 41.2 & 41.2 & 97.1 \\
Market center & 1 & 2.9 & 2.9 & 100.0 \\
Total & 34 & 100.0 & 100.0 & \\
\hline
\end{tabular}


Table 5 Distribution of students' residential location by distance from nearest urban center

\begin{tabular}{lcccc}
\hline & Frequency & Percent & $\begin{array}{c}\text { Valid } \\
\text { Percent }\end{array}$ & $\begin{array}{c}\text { Cumulative } \\
\text { Percent }\end{array}$ \\
\hline Less 10km & 17 & 50.0 & 50.0 & 50.0 \\
$11-20 \mathrm{~km}$ & 8 & 23.5 & 23.5 & 73.5 \\
$21-30 \mathrm{~km}$ & 3 & 8.8 & 8.8 & 82.4 \\
Over 30km & 6 & 17.6 & 17.6 & 100.0 \\
Total & 34 & 100.0 & 100.0 & \\
\hline
\end{tabular}

Table 6 Distribution of students by school location $\quad \mathrm{N}=34$

\begin{tabular}{ccc}
\hline School location & Frequency & Percentage \\
\hline Western & 13 & 38 \\
Rift Valley & 7 & 21 \\
Nyanza & 7 & 21 \\
Central & 4 & 11 \\
Nairobi & 3 & 9 \\
Total & 34 & 100 \\
\hline
\end{tabular}


Student' Leadership in Selected Public Universities in Kenya...

Table 7: Distribution of students by their roles in secondary school administration $\quad N=34$

\begin{tabular}{lcc}
\hline $\begin{array}{l}\text { Role in school } \\
\text { administration }\end{array}$ & Frequency & Percentage* \\
\hline Sports captain & 9 & 25 \\
School prefect & 7 & 21 \\
House captain & 6 & 18 \\
Clubs and societies & 4 & 12 \\
Class prefect & 2 & 6 \\
None & 6 & 18 \\
Total & 34 & 100 \\
\hline
\end{tabular}

Table 8: Reasons for interest in student leadership $\quad \mathrm{N}=34$

\begin{tabular}{lcc}
\hline Reasons & Frequency & Percentage* \\
\hline Serve student interests & 25 & 73 \\
A learning exercise and personal development & 17 & 50 \\
$\begin{array}{l}\text { Harmonize students and university } \\
\text { management }\end{array}$ & 9 & 24 \\
Interest in leadership/innate motivation & 5 & 15 \\
Motivation by role models & 2 & 6 \\
\hline
\end{tabular}

* Totals cannot add up to $100 \%$ due to multiple responses 
Table 9: Challenges to student leadership in public universities $\quad \mathbf{N}=\mathbf{3 4}$

\begin{tabular}{lcc}
\hline \multicolumn{1}{c}{ Challenges } & Frequency & Percentage* \\
\hline High student expectations & 18 & 53 \\
$\quad$ Conflict between academic pursuits and & 17 & 50 \\
$\quad$ leadership roles & 12 & 35 \\
Financial constraints in student organizations & 10 & 29 \\
Institutional rigidities and bureaucracy & 9 & 24 \\
Fear of victimization & 8 & 23 \\
False image of student solidarity & 4 & 12 \\
Student ignorance of university statutes & 1 & 3 \\
External influences and interferences & \multicolumn{2}{c}{ * Totals cannot add up to 100\% due to multiple responses }
\end{tabular}

Table 10: Causes of student activism in public universities $\quad \mathrm{N}=34$

\begin{tabular}{|c|c|c|}
\hline Causes & Frequency & Percentage* \\
\hline Student pressure and propaganda & 20 & 59 \\
\hline Poor administration models & 16 & 47 \\
\hline $\begin{array}{l}\text { External pressure from other campuses and national } \\
\text { politics }\end{array}$ & 13 & 38 \\
\hline Ethnicity & 7 & 21 \\
\hline Poor academic environment & 6 & 18 \\
\hline Poor infrastructure on campus & 4 & 12 \\
\hline
\end{tabular}

\footnotetext{
* Totals cannot add up to $100 \%$ due to multiple responses
} 